\title{
Poliovirus-Specific Primer-Dependent RNA Polymerase Able to Copy Poly(A)
}

James B. Flanegan, and David Baltimore

PNAS 1977;74;3677-3680

doi:10.1073/pnas.74.9.3677

This information is current as of December 2006.

E-mail Alerts

Rights \& Permissions

Reprints
This article has been cited by other articles:

www.pnas.org\#otherarticles

Receive free email alerts when new articles cite this article - sign up in the box at the top right corner of the article or click here.

To reproduce this article in part (figures, tables) or in entirety, see:

www.pnas.org/misc/rightperm.shtml

To order reprints, see:

www.pnas.org/misc/reprints.shtml

Notes: 


\title{
Poliovirus-specific primer-dependent RNA polymerase able to copy poly(A)
}

[RNA-dependent RNA polymerase (replicase)/picornaviruses]

\author{
James B. Flanegan and David Baltimore
}

Department of Biology, and Center for Cancer Research, Massachusetts Institute of Technology, Cambridge, Massachusetts 02139

Contributed by David Baltimore, June 9, 1977

\begin{abstract}
A template-dependent RNA polymerase has been isolated from poliovirus-infected cells by assaying for the ability of the enzyme to copy poly(A) complexed to an oligo(U) primer. The polymerase was solubilized with detergent, and RNA was removed by precipitation with $2 \mathrm{M} \mathrm{LiCl}$. The solubilized polymerase required both poly $(A)$ and oligo(U) for activity and was stimulated by $\mathbf{M g}^{2+}$ but was inhibited by $\mathbf{M n}^{2+}$. Poly(A) • oligo(U)-dependent poly(U) polymerase was not found in extracts of HeLa cells until about $2 \mathrm{hr}$ after poliovirus infection, and then there was a linear increase in activity until about $5 \mathrm{hr}$. Analysis of the polymerase by glycerol gradient centrifugation showed that the majority of the activity sedimented at about $4 \mathrm{~S}$, indicating that it was no longer complexed with high-molecular-weight RNA or cellular membranes. This poly $(A) \cdot$ oligo(U)-dependent polymerase activity could represent an important component of the poliovirus RNA-dependent RNA polymerase.
\end{abstract}

An RNA-dependent RNA polymerase (replicase) is found in the cytoplasm of cells infected with poliovirus (1) as well as with other picornaviruses $(2,3)$ and is apparently responsible for the replication of the viral RNA genome. Previous attempts to purify the poliovirus replicase as a soluble enzyme were limited by the lack of an assay for enzymatic activity with an exogenously supplied RNA template. Studies have been restricted to the purification and characterization of the replicase complexed to the endogenous RNA template (4-7) which was found to be associated with cellular membranes $(4,8-10)$. A soluble replicase-template complex could be prepared by detergent treatment of the membrane fraction, followed by precipitation of the complex with $2 \mathrm{M} \mathrm{LiCl} \mathrm{(4-6).} \mathrm{Several} \mathrm{host} \mathrm{and} \mathrm{viral}$ polypeptides were found in the precipitate, the predominant one being noncapsid viral protein 4. Previous attempts to stimulate the replicase activity by the addition of exogenous RNA were not successful (4). A template-dependent replicase has been isolated from encephalomyocarditis virus-infected cells, but it was highly unstable (11).

The detailed mechanisms involved in the replication of the single-stranded RNA genome of poliovirus are not known. The synthesis of poliovirus messenger and virion RNA (plus strands) takes place in a structure known as the replicative intermediate (12-14). The replicative intermediate consists of at least one complete strand of complementary (negative strand) RNA and approximately six nascent chains of plus strand RNA (14). The first step in the formation of the replicative intermediate should be the synthesis of a complete negative strand RNA molecule. During synthesis of the negative strand, assuming that it occurs $5^{\prime}$ to $3^{\prime}$, the initial event would be copying of the poly(A) at the $3^{\prime}$ end of the virion RNA to form the poly $(U)$ found at the $5^{\prime}$ end of negative strand RNA $(15,16)$. Thus, negative strand synthesis

The costs of publication of this article were defrayed in part by the payment of page charges. This article must therefore be hereby marked "advertisement" in accordance with 18 U. S. C. $\$ 1734$ solely to indicate this fact. should be initiated by a poly(A)-dependent poly(U) polymerase. This reasoning led us to investigate if poliovirus-infected cells might contain a poly(A)-dependent poly(U) polymerase. Initial attempts to use poly(A) as a template revealed no such activity, but when oligo(U) was added as a potential primer, an active poly $(U)$ synthesis was observed. We report here the identification and partial purification of a poliovirus-specific $\operatorname{poly}(A) \cdot$ oligo $(U)$-dependent poly $(U)$ polymerase.

\section{MATERIALS AND METHODS}

Preparation of Infected Cell Extracts. HeLa cells were grown in suspension culture and infected with poliovirus type 1 as described (17). At 3-6 hr postinfection, $100 \mathrm{ml}$ of infected cells $\left(4 \times 10^{6} / \mathrm{ml}\right)$ were collected by centrifugation, washed once in Earle's saline, and resuspended in $10 \mathrm{ml}$ of $0.01 \mathrm{M}$ Tris $\cdot \mathrm{HCl}, \mathrm{pH}$ 8.0/0.01 M NaCl (TN buffer). A cytoplasmic extract was prepared by breaking the cells in a Dounce homogenizer and removing the nuclei by centrifugation (5000 $\times g$ for $5 \mathrm{~min}$ ).

Isolation of the Poly(U) Polymerase. The membrane fraction of the cytoplasmic extract was deposited by centrifugation at $20,000 \times g$ for $30 \mathrm{~min}$. The supernatant was removed and the pellet was resuspended in 1 volume of TN buffer containing $1 \%$ (vol/vol) Nonidet P-40 (NP-40), 0.5\% (wt/vol) sodium deoxycholate (DOC), and $2 \mathrm{M} \mathrm{LiCl}$. After $15 \mathrm{hr}$ at $-20^{\circ}$, the precipitate containing single-stranded and replicative intermediate RNA was removed by centrifugation at $17,000 \times g$ for $15 \mathrm{~min}$. The resulting supernatant was dialyzed for $5 \mathrm{hr}$ and then for $15 \mathrm{hr}$ against 2-liter portions of TN buffer at $4^{\circ}$. One milliliter of the dialyzed supernatant was derived from about $4 \times 10^{7}$ infected cells.

Assay of Polymerase Activity. In a standard reaction, a 50- $\mu \mathrm{l}$ aliquot of enzyme was assayed in $125 \mu$ l of solution containing $50 \mathrm{mM} N$-2-hydroxyethylpiperazine- $N^{\prime}$-2-ethanesulfonic acid (Hepes) buffer (pH 8.0), $8 \mathrm{mM} \mathrm{Mg}\left(\mathrm{CH}_{3} \mathrm{COO}\right)_{2}, 0.08 \mathrm{mM}$ $\left[5,6^{-3} \mathrm{H}\right]$ UTP $(110-550 \mathrm{cpm} / \mathrm{pmol}), \operatorname{poly}(\mathrm{A})(20 \mu \mathrm{g} / \mathrm{ml})$, oligo $(\mathrm{U})_{11-19}(10 \mu \mathrm{g} / \mathrm{ml}), 4 \mathrm{mM}$ phosphoenolpyruvic acid, pyruvate kinase ( 3 international units $/ \mathrm{ml}$ ), and actinomycin $\mathrm{D}(10 \mu \mathrm{g} / \mathrm{ml})$. The assay was at either $37^{\circ}$ or $29^{\circ}$. The rate of UMP incorporation at the lower temperature was linear for a longer time. Enzymatic activity was measured as the amount of labeled product collected on $0.45-\mu \mathrm{m}$ membrane filters (Millipore) after precipitation in 7\% trichloroacetic acid (TCA) sodium pyrophosphate (1:3 saturated) with $200 \mu \mathrm{g}$ of added carrier RNA. The filters were assayed in Bray's scintillation fluid (New England Nuclear) with a Beckman LS-230 scintillation counter.

Abbreviations: replicase, RNA-dependent RNA polymerase; TN buffer, 0.01 M Tris-HCl, pH 8.0/0.01 M NaCl; NP-40, Nonidet P-40; DOC, sodium deoxycholate; DTT, dithiothreitol. 


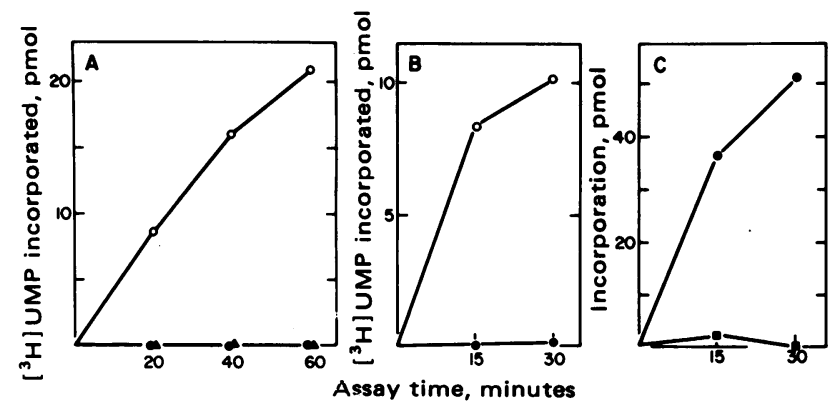

FIG. 1. The poly(A), oligo(U), and ribonucleoside triphosphate requirements of the RNA polymerase solubilized from poliovirusinfected cells. $(A)$ Polymerase activity with UTP as the only added substrate. A dialyzed $\mathrm{LiCl}$ supernatant was prepared from cells infected for $3.5 \mathrm{hr}$ and was assayed for polymerase activity at $37^{\circ}$ as described in Materials and Methods except that poly(A) was used at $200 \mu \mathrm{g} / \mathrm{ml}$, and $80 \mu \mathrm{M}\left[{ }^{3} \mathrm{H}\right] \mathrm{UTP}$ was the only added ribonucleoside triphosphate. The amount of labeled UMP incorporated was measured in the presence of added poly $(A)(\Delta)$, oligo(U) $(\bullet)$, or both poly $(A)$ and oligo $(U)(O)$. (B) Polymerase activity with $\left[{ }^{3}\right.$ H]UTP plus unlabeled GTP, CTP, and ATP. The conditions and symbols were as in $A$ except that polymerase activity was measured with $80 \mu \mathrm{M}$ [ $\left.{ }^{3} \mathrm{H}\right]$ UTP plus ATP, GTP, and CTP, all at a final concentration of 200 $\mu \mathrm{M}$. (C) Polymerase activity with $\left[{ }^{3} \mathrm{H}\right] \mathrm{GTP}$ and $\left[{ }^{3} \mathrm{H}\right] \mathrm{UTP}$. The conditions were as in $A$ except that a different preparation of enzyme was used in which $1 \% \mathrm{NP}-40$ and $2 \mathrm{M} \mathrm{LiCl}$ were used to solubilize the cellular membranes without added DOC. The polymerase was assayed in the presence of poly(A) and oligo(U) with either $80 \mu \mathrm{M}\left[{ }^{3} \mathrm{H}\right] \mathrm{UTP}$ $(\bullet)$ or $80 \mu \mathrm{M}\left[{ }^{3} \mathrm{H}\right] \mathrm{GTP}(\boldsymbol{\square})$ as the only added ribonucleoside triphosphates.

Materials. All labeled nucleotides were obtained from New England Nuclear Corp. in solution in 50\% ethanol; after evaporation to dryness, the solid was resuspended in sterile water at $1 / 10$ the original volume. Unlabeled nucleotides and pyruvate kinase were obtained from Calbiochem, poly(A) was from Miles Laboratories, oligo $(\mathrm{U})_{11-19}$ and oligo $(\mathrm{dT})_{12-18}$ were from Collaborative Research, and actinomycin D was a gift of Merck Sharp and Dohme.

\section{RESULTS}

Identification of the Polymerase. The poly $(U)$ polymerase was first detected in a solubilized membrane fraction of poliovirus-infected HeLa cells. Membranes were prepared from a cytoplasmic extract of cells infected for $3.5 \mathrm{hr}$ and resuspended in a solution of $1 \% \mathrm{NP}-40,0.5 \% \mathrm{DOC}$, and $2 \mathrm{M} \mathrm{LiCl}$. All single-stranded and replicative intermediate RNA was allowed to precipitate at $-20^{\circ}$ and then removed by centrifugation. After the $\mathrm{LiCl}$ was removed from the resulting supernatant by dialysis, a polymerase was found that synthesized $\operatorname{poly}(\mathrm{U})$ with poly $(\mathrm{A})$ as the template, oligo(U) as the primer, and labeled UTP as the only substrate (Fig. 1A). Both poly(A) and oligo(U) were required for activity (Fig. $1 A$ and Table 1 ), suggesting that the polymerase was only active on a duplex structure of template and primer. Replacing the oligo $(\mathrm{U})_{11-19}$ primer with an oligo $(\mathrm{dT})_{12-18}$ primer resulted in a complete loss of activity (Table 1). When all four ribonucleoside triphosphates were present, addition of both poly(A) and oligo(U) was still required for activity (Fig. $1 B$ ), suggesting that all of the endogenous RNA template was removed by $\mathrm{LiCl}$ precipitation. There was no significant incorporation of the noncomplementary nucleotides GMP (Fig. IC) or CMP (data not shown) in the presence of added poly(A) and oligo(U). Thus, the dialyzed $\mathrm{LiCl}$ supernatant does not support a nonspecific terminal addition of ribonucleotides to either homopolymer. When $\mathbf{M g}^{2+}$ was replaced by $\mathrm{Mn}^{2+}$, less than $10 \%$ of the original polymerase
Table 1. Template, primer, and divalent cation requirements for polymerase activity

\begin{tabular}{|c|c|c|}
\hline Additions & $\begin{array}{c}{\left[{ }^{3} \mathrm{H}\right] \mathrm{UMP}} \\
\text { incorporated, pmol }\end{array}$ & $\begin{array}{c}\% \text { of } \\
\text { control }\end{array}$ \\
\hline \multicolumn{3}{|c|}{ Experiment 1} \\
\hline $\operatorname{Poly}(A)$, oligo $(U)_{11-19}$ & 10.4 & 100 \\
\hline None & $<0.5$ & $<5$ \\
\hline Oligo(U) $)_{11-19}$ & $<0.5$ & $<5$ \\
\hline $\operatorname{Poly}(A)$ & 0.5 & 5 \\
\hline Oligo $(d T)_{12-18}$ & $<0.5$ & $<5$ \\
\hline Oligo $(\mathrm{dT})_{12-18}, \operatorname{poly}(\mathrm{A})$ & $<0.5$ & $<5$ \\
\hline \multicolumn{3}{|c|}{ Experiment 2} \\
\hline $8 \mathrm{mM} \mathrm{MgCl} 2$ & 23.5 & 100 \\
\hline None & $<0.5$ & $<2$ \\
\hline $8 \mathrm{mM} \mathrm{MnCl}{ }_{2}$ & 1.9 & 8 \\
\hline $8 \mathrm{mM} \mathrm{MgCl} 2,5 \mathrm{mM} \mathrm{MnCl}{ }_{2}$ & 2.5 & 11 \\
\hline
\end{tabular}

The poly(U) polymerase in the dialyzed $\mathrm{LiCl}$ supernatant was prepared and assayed as described in Materials and Methods with the following modifications. In experiment 1 , the assay mixture contained poly(A) $(20 \mu \mathrm{g} / \mathrm{ml})$, oligo(U) $)_{11-19}(10 \mu \mathrm{g} / \mathrm{ml})$, oligo $(\mathrm{dT})_{12-18}$ $(10 \mu \mathrm{g} / \mathrm{ml})$, or combinations as indicated. In experiment 2 , a different enzyme preparation was used and the divalent cation concentrations were as indicated. For each assay in experiment 2 , poly(A) $(20 \mu \mathrm{g} / \mathrm{ml})$, oligo(U) $)_{11-19}(10 \mu \mathrm{g} / \mathrm{ml})$, and $10 \mathrm{mM}$ DTT were present. The assays were for $30 \mathrm{~min}$ at $29^{\circ}$.

activity remained and $\mathrm{Mn}^{2+}$ inhibited the activity stimulated by $\mathrm{Mg}^{2+}(\mathrm{Table} 1) . \mathrm{Mn}^{2+}$ is also known to inhibit the endogenous replicase activities of poliovirus and Mengovirus $(1,2)$. The poly $(\mathrm{U})$ polymerase did not show an absolute requirement for dithiothreitol (DTT) but its activity was stimulated by about $50 \%$ in the presence of added DTT (data not shown).

Poly(A) - oligo(U) could stimulate poly $(U)$ synthesis in crude cytoplasmic extracts and most of the activity sedimented with the cellular membranes. Various procedures were used to solubilize the activity from the membrane pellet. Using $1 \%$ NP-40 and $2 \mathrm{M} \mathrm{LiCl}$ without added DOC resulted in a $30 \%$ increase in activity, but a precipitate was formed after the final dialysis step that contained most of the polymerase activity (data not shown). When 2 or $4 \mathrm{M} \mathrm{LiCl}$ was used without added detergent, only about half of the activity was recovered compared to that found with $\mathrm{NP}-40 / \mathrm{DOC} / 2 \mathrm{M} \mathrm{LiCl}$. Using $2 \mathrm{mM}$ EDTA in combination with $2 \mathrm{M} \mathrm{LiCl}$ resulted in even lower yields.

The Poly(U) Polymerase Is Poliovirus-Specific. The $\operatorname{poly}(A) \cdot \operatorname{oligo}(U)$-dependent poly $(U)$ polymerase was not detectable in the dialyzed $\mathrm{LiCl}$ supernatant prepared from uninfected HeLa cells and first became evident about $2 \mathrm{hr}$ after poliovirus infection (Fig. 2). The increase in enzyme activity coincided with the start of detectable virus-specific RNA synthesis and continued linearly until $5 \mathrm{hr}$ after infection. Similar results were reported for endogenous poliovirus replicase activity, but this activity reached a maximum value much earlier and then decreased with kinetics similar to those found for the rate of RNA synthesis within the infected cell $(1,4,7)$. Assuming that the poly $(\mathrm{A}) \cdot$ oligo(U)-dependent activity reflects the activity of the poliovirus replicase, these results suggest that the decrease in the endogenous activity at late infection times may not result from an inherent instability in the replicase itself. Rather, the decreased activity may result from a degradation of the endogenous RNA template or from the loss of some other factor required to initiate RNA synthesis.

Analysis of the RNA Product. The product synthesized in vitro in the presence of added poly $(\mathrm{A})$, oligo(U), and labeled UTP was completely converted to acid solubility by digestion 


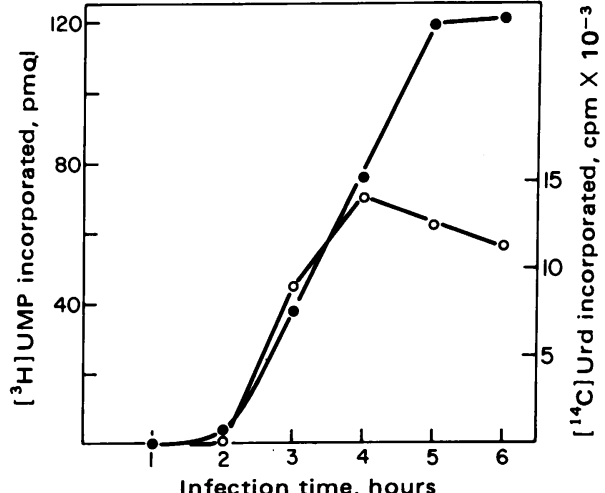

FIG. 2. The appearance of $\operatorname{poly}(A)$-oligo(U)-dependent poly(U) polymerase activity in HeLa cells after poliovirus infection. Aliquots of a poliovirus-infected culture containing $5 \mu \mathrm{g} / \mathrm{ml}$ of actinomycin $\mathrm{D}$ were taken at the indicated times and a dialyzed $\mathrm{LiCl}$ supernatant was prepared at each time point using $1 \% \mathrm{NP}-40$ and $2 \mathrm{M} \mathrm{LiCl}$ without added DOC. Assays for polymerase activity $(\bullet)$ were at $37^{\circ}$ for $30 \mathrm{~min}$ as described in Materials and Methods with poly(A) $(200 \mu \mathrm{g} / \mathrm{ml})$ and oligo(U) $(10 \mu \mathrm{g} / \mathrm{ml})$ and $80 \mu \mathrm{M}\left[{ }^{3} \mathrm{H}\right] \mathrm{UTP}$ as the only ribonucleoside triphosphate. RNA synthesis $(O)$ in the infected culture was measured by adding $\left[{ }^{14} \mathrm{C}\right]$ Urd $(0.5 \mu \mathrm{Ci} / \mathrm{ml})$ to a portion of the culture and measuring the amount of the radioactivity incorporated into acid-insoluble material in 0.1-ml aliquots of the culture taken at the indicated times.

with either ribonuclease or $0.5 \mathrm{M} \mathrm{NaOH}$ but was not affected by deoxyribonuclease digestion (Table 2). When $\left[\alpha^{-32} \mathrm{P}\right] \mathrm{UTP}$ was used as the substrate, a nearest neighbor analysis indicated that the polymerase product was poly $(\mathrm{U})$ because the $\alpha-{ }^{32} \mathrm{P}$ in labeled UMP residues was only transferred to other UMP residues (Table 3). If UMP residues were ever incorporated next to AMP or any other nucleotide, incorporation must have occurred at a frequency of less than about $1 / 1000$. In addition, the above results rule out the possibility that UMP residues are being incorporated into poliovirus double-stranded RNA by a repair mechanism similar to that recently proposed by Yin (7).

Glycerol Gradient Centrifugation of the Polymerase. The poly $(\mathrm{U})$ polymerase in the dialyzed $\mathrm{LiCl}$ supernatant was analyzed by centrifugation on a linear 5-20\% glycerol gradient (Fig. 3). The majority of the polymerase activity sedimented

Table 2. Digestion of the labeled product with RNase, DNase, and $\mathrm{NaOH}$

\begin{tabular}{lc}
\hline \multicolumn{1}{c}{ Digestion conditions } & \% of control \\
\hline Untreated & 100 \\
DNase I & 98 \\
Takadiastase + RNase A & 6 \\
$0.5 \mathrm{M} \mathrm{NaOH}, 20$ min at $80^{\circ}$ & 3 \\
\hline
\end{tabular}

The reaction conditions were as described in Materials and Methods except that $\left[\alpha^{-}{ }^{32} \mathrm{P}\right] \mathrm{UTP}$ was used as the labeled substrate. For nuclease digestion, the product was first purified by chromatography of the reaction mixture on a Sephadex G-50 column in $0.4 \mathrm{M}$ triethylamine carbonate. The void volume of the column, which contained the labeled product [presumably hydrogen-bonded to poly(A)], was lyophilized and digested with pancreatic DNase I (Worthington) in $5 \mathrm{mM} \mathrm{MgSO}_{4} / 100 \mathrm{mM}$ sodium acetate $(\mathrm{pH} \mathrm{5.0)}$ ) at $25^{\circ}$ or with takadiastase plus RNase A (20). Prior to digestion with takadiastase plus RNase $A$, the purified product was incubated at $100^{\circ}$ for $2 \mathrm{~min}$ and then rapidly cooled. To test for alkali sensitivity, a control sample was precipitated with TCA, and a test sample was placed in $\mathrm{NaOH}$ and heated as indicated. After cooling, sufficient TCA was added to neutralize the $\mathrm{NaOH}$ and give a final concentration of $5 \%$ TCA. The treated and untreated samples were then filtered and assayed for radioactivity.
Table 3. Nearest neighbor analysis of the product synthesized with added poly(A), oligo(U), and [ $\left.\alpha-{ }^{32} \mathrm{P}\right] \mathrm{UTP}$

\begin{tabular}{ccc}
\hline $3^{\prime}$-Nucleotide & cpm & \% of total \\
\hline UMP & 9446 & 99.7 \\
GMP & $<10$ & $<0.1$ \\
AMP & $<10$ & $<0.1$ \\
CMP & $<10$ & $<0.1$ \\
\hline
\end{tabular}

The reaction conditions were the same as in Materials and Methods except that the substrate was $\left[\alpha-{ }^{32} \mathrm{P}\right] \mathrm{UTP}$. The product was precipitated in 5\% TCA, digested with $0.4 \mathrm{M} \mathrm{KOH}$ at $37^{\circ}$ for $20 \mathrm{hr}$, neutralized by passing it through a Chelex 100 column ( $\mathrm{H}^{+}$form) (Bio$\mathrm{Rad}$ ), and analyzed by high-voltage electrophoresis at $\mathrm{pH} 3.5$ on Whatman $3 \mathrm{MM}$ paper with ${ }^{32} \mathrm{P}$-labeled ribonucleoside $3^{\prime}$-monophosphate markers in parallel lanes.

at about $4 \mathrm{~S}$ relative to the $4.6 \mathrm{~S}$ sedimentation marker (bovine serum albumin, molecular weight 68,500 ). This indicated that the NP-40/DOC/2 M LiCl treatment solubilized the majority (about $80 \%$ ) of the poly $(U)$ polymerase activity and that the polymerase was no longer complexed with either high molecular weight RNA or cellular membranes. The size of the poly $(U)$ polymerase is apparently within the molecular weight range of the two stable noncapsid poliovirus-specific proteins, 3 $(70,000)$ and $4(57,000)$.

\section{DISCUSSION}

In the search for a poliovirus replicase, previous studies have depended on the activity of the enzyme with endogenous viral RNA as template. Attempts to stimulate activity with added viral RNA have failed. We have approached the problem by assaying for a model activity of the replicase. Reasoning that minus strand synthesis involves poly $(\mathrm{U})$ synthesis as its first step, we assayed for poly(A)-dependent poly(U) synthesis. Because we had previously had success assaying reverse transcriptase with polymer templates and oligomer primers (18), when poly $(\mathbf{A})$ by itself did not stimulate poly $(\mathrm{U})$ synthesis, we added oligo(U) as a potential primer.

Our ability to assay poly $(\mathrm{A}) \cdot \operatorname{oligo}(\mathrm{U})$-dependent poly $(\mathrm{U})$ synthesis in poliovirus-infected cells, but not in uninfected cells, suggests that we have demonstrated a new virus-related enzymatic activity. Whether this is the replicase itself, or even a portion of the replicase, remains to be shown. A suggestion that

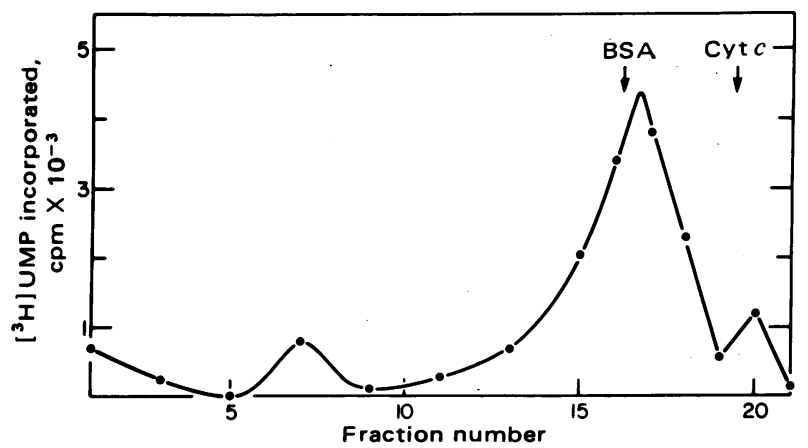

FIG. 3. Glycerol gradient centrifugation of the poly(A)-oligo(U)dependent poly(U) polymerase. A dialyzed $\mathrm{LiCl}$ supernatant was prepared from poliovirus-infected cells $(5.5 \mathrm{hr}$ ) and a $0.7-\mathrm{ml}$ portion was layered on a linear 5-20\% ( $\mathrm{vol} / \mathrm{vol})$ glycerol gradient $(10.5 \mathrm{ml})$ prepared in TN buffer. The gradient was centrifuged in a Beckman SW-41 rotor at $35,000 \mathrm{rpm}$ at $4^{\circ}$ for $19 \mathrm{hr}$ and was collected from the bottom in $0.5-\mathrm{ml}$ fractions which were assayed for $60 \mathrm{~min}$ at $29^{\circ}$ as described in Materials and Methods with $10 \mathrm{mM}$ DTT added. The sedimentation markers [ ${ }^{125}$ I-labeled bovine serum albumin (BSA) and horse heart cytochrome $c$ (Cyt $c$ )] were run under identical conditions in a parallel gradient. 
the $\mathrm{LiCl}$ supernatant fraction can copy heteropolymers as well as poly(A) has been obtained: poliovirion RNA will support incorporation of labeled UMP or GMP in this fraction in the presence of all four ribonucleoside triphosphates and oligo(U) (J. B. Flanegan and D. Baltimore, unpublished data).

We previously found that poliovirion RNA is not infectious if its $3^{\prime}-\operatorname{poly}(\mathbf{A})$ has been removed (19). If the replicase does initiate minus strand synthesis by making $\operatorname{poly}(\mathrm{U})$, it may be unable to copy poly(A)-deficient RNA, thus explaining the requirement of poly $(A)$ for infectivity.

The dependence of poly $(\mathrm{U})$ synthesis on an oligo(U) primer suggests that the replication of poliovirus RNA could also be dependent on a preformed primer. A protein has been found covalently linked to the $5^{\prime}$ termini of poliovirion and replicative intermediate RNAs $(20,21)$. Such a 5'-terminal protein, possibly with one or more nucleotides attached, could be a natural primer for synthesis of plus strand RNA. Whether such a model is relevant to minus strand synthesis will depend on whether there is a protein linked to the $5^{\prime}$ ends of minus strands.

The requirement for a preformed primer has recently been reported for another viral RNA polymerase. Plotch and Krug (22) found that the endogenous activity of the influenza virion RNA transcriptase was stimulated 100 -fold in the presence of certain specific dinucleoside monophosphates. These were shown to act as primers for the synthesis of RNA by the viral transcriptase. Thus, certain RNA polymerases, like all DNA polymerases, may be primer-dependent enzymes.

We gratefully acknowledge the helpful suggestions of Dr. Ralf Pettersson and Dr. John Rose and the excellent technical assistance of Kahan Smith and Victor Ambros. This work was supported by Grants AI08388, CA 12174, and CA 14051 from the National Institutes of Health. J.B.F. is the recipient of a National Institutes of Health Postdoctoral Fellowship F32 AI05179. D.B. is a Research Professor of the American Cancer Society.
1. Baltimore, D., Eggers, H. J., Franklin, R. M. \& Tamm, I. (1963) Proc. Natl. Acad. Sci. USA 49, 843-849.

2. Baltimore, D. \& Franklin, R. M. (1962) Biochem. Biophys. Res. Commun. 9, 388-392.

3. Dalgarno, L. \& Martin, E. M. (1965) Virology 26, 450-456.

4. Ehrenfeld, E., Maizel, J. V. \& Summers, D. F. (1970) Virology 40, 840-846.

5. Lundquist, R. E., Ehrenfeld, E. \& Maizel, J. V. (1974) Proc. Natl. Acad. Sci. USA 71, 4773-4777.

6. Butterworth, B. E., Shimshick, E. J. \& Yin, F. H. (1976) J. Virol. $19,457-466$.

7. Yin, F. H. (1977) J. Virol. 21, 61-68.

8. Baltimore, D. (1964) Proc. Natl. Acad. Sci. USA 51, 450-456.

9. Caliguiri, L. A. \& Tamm, I. (1970) Virology 42, 100-111.

10. Caliguiri, L. A. \& Tamm, I. (1970) Virology 42, 111-121.

11. Traub, A., Diskin, B., Rosenberg, H. \& Kalmar, E. (1976) J. Virol. 18, 375-382.

12. Baltimore, D. \& Girard, M. (1966) Proc. Natl. Acad. Sci. USA 56, 741-748.

13. Girard, M., Baltimore, D. \& Darnell, J. E. (1967) J. Mol. Biol. 24, 59-74.

14. Baltimore, D. (1968) J. Mol. Biol. 32, 359-368.

15. Spector, D. H. \& Baltimore, D. (1975) Virology 67, 498-505

16. Yogo, Y. \& Wimmer, E. (1975) J. Mol. Biol. 92, 467-477.

17. Villa-Komaroff, L., McDowell, M., Baltimore, D. \& Lodish, H. F. (1974) in Methods in Enzymology, eds. Moldave, K. \& Grossman, L. (Academic Press, New York), Vol. 30, Part F, pp. 709-723.

18. Baltimore, D. \& Smoler, D. (1971) Proc. Natl. Acad. Sci. USA 68, 1507-1511.

19. Spector, D. H. \& Baltimore, D. (1974) Proc. Natl. Acad. Sci. USA 71, 2983-2987.

20. Flanegan, J. B., Pettersson, R. F., Ambros, V., Hewlett, M. J. \& Baltimore, D. (1977) Proc. Natl. Acad. Sci. USA 74, 961-965.

21. Lee, Y. F., Nomoto, A., Detjen, B. M. \& Wimmer, E. (1977) Proc. Natl. Acad. Sci. USA 74, 59-63.

22. Plotch, S. J. \& Krug, R. M. (1977) J. Virol. 21, 24-34. 